\title{
Interactive comment on "On the stability interpretation of Extended Column Test results" by Frank Techel et al.
}

\section{Frank Techel et al.}

techel@slf.ch

Received and published: 5 May 2020

Thank you for posting this interesting graph, which highlights the variations between operators performing the ECT. Unfortunately, these findings do not seem to be published. However, there seems to have been a similar analysis more than ten years ago for the Compression Test (CT) by Spencer Logan (2008: Are you a hard hitter? Systematic measurement error in the compression test) https://arc.lib.montana.edu/ snow-science/objects/issw-2006-682.pdf Unfortunately, only an abstract without any results is available.

Printer-friendly version

We will take up your suggestion to discuss the limitations of the ECT in greater depth. 
2020-50, 2020.

NHESSD

Interactive

comment

Printer-friendly version

Discussion paper 